\title{
Correction to: A research note on accountability and institutional clarity: how two dimensions of clarity of responsibility moderate accountability mechanisms
}

\section{Lisanne de Blok $^{1}$ (D) Wouter van der Brug $^{2}$}

Published online: 12 February 2022

(c) Springer Nature Limited 2022

\section{Correction to: Acta Politica https://doi.org/10.1057/s41269-021-00228-1}

The authors realized that the page numbers were not updated in the following references after the original publication of the article. Now, the correct references are given below:

de Blok, L., W. van der Brug, and T.W.G. van der Meer. 2020. Policy area satisfaction, perceptions of responsibility, and political trust: A novel application of the REWB model to testing evaluation-based political trust. Journal of Elections, Public Opinion \& Parties https://doi.org/10.1080/17457289.2020.1780433

Duch, R. M., H.D. Palmer, and C.J. Anderson. 2000. Heterogeneity in perceptions of national economic conditions. American Journal of Political Science 44 (4): 635-652.

Hix, S., and A. Follesdal. 2006. Why there is a democratic deficit in the EU: A response to Majone and Moravcsik. Journal of Common Market Studies 44 (3): 533-562 https://doi.org/10.1111/j.1468-5965.2006.00650.x.

Konstantinidis, N., K. Matakos, and H. Mutlu-Eren. 2019. "Take back control"? The effects of supranational integration on party system polarization. Review of International Organizations 14: 297-333.

León, S., I. Jurado, and A. Garmendia Madariaga. 2018. Passing the buck? Responsibility attribution and cognitive bias in multilevel democracies. West European Politics 44 (3): 660-682.

The original article can be found online at https://doi.org/10.1057/s41269-021-00228-1.

Lisanne de Blok

e.a.deblok@uu.nl

Wouter van der Brug

w.vanderbrug@uva.nl

1 Utrecht University, Utrecht, The Netherlands

2 Universiteit van Amsterdam, Amsterdam, The Netherlands

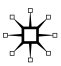


The original article has been corrected.

Publisher's Note Springer Nature remains neutral with regard to jurisdictional claims in published maps and institutional affiliations. 